\title{
STUDI LITERATUR: PENGARUH HIPNOSIS TERHADAP PENURUNAN KECEMASAN PADA PASIEN KANKER
}

\author{
Gandi Iswanto $^{\bowtie}$, Rini Rachmawaty, Julianus Ake \\ Program Studi Magister Ilmu Keperawatan Universitas Hasanuddin Makassar
}

\begin{tabular}{l} 
ARTICLE INFO \\
\hline Article history \\
Submitted : 2020-11-30 \\
Revised : 2020-12-06 \\
Accepted : 2020-12-27 \\
Keywords: \\
Hypnosis \\
Cancer patients \\
Effectiveness of hypnosis \\
Reduce anxiety
\end{tabular}

\section{Kata Kunci:}

Hipnosis

Pasien kanker

Efektifitas hipnosis

Menurunkan kecemasan

\begin{abstract}
One of the most common problems among patients with cancer is anxiety and it can cause other physiological problems caused by anxiety. This literature review aimed to review the literature on the effect of hypnosis on reducing anxiety in cancer patients. The research design used was a literature review. The search for articles used several databases, including Pubmed, Google Scholar, with the keyword Hypnosis, Hypnosis in cancer patients, the effectiveness of hypnosis, hypnosis to lower reports. The type of article used was research articles. Collected articles were reselected based on inclusion criteria, namely: 1) The purpose of the article was to analyze the effect of hypnosis on reducing anxiety in cancer patients, 2) experimental and qualitative research. Exclusion Criteria, namely: 1) not a full text article, 2) Articles that use languages other than Indonesian and English. After searching based on keywords, we obtained 791 articles from the entire database used. Then the article selection was carried out, 6 articles were selected that met the inclusion criteria, 5 articles showed the effect of hypnosis on reducing anxiety in cancer patients, 1 article stated that hypnosis with 3 stages was more optimal for reducing anxiety, namely; self hypnosis, suggestion, visualization offers restraint. Based on the foregoing, it is concluded that hypnosis has an effect on reducing anxiety in cancer patients.

Salah satu masalah yang paling sering muncul pada pasien dengan kasus kanker adalah kecemasan dan dapat menimbulkan masalah fisiologis lain yang diakibatkan oleh kecemasan. Tujuan Literature review adalah untuk menganalisis tinjauan literatur pengaruh hipnosis terhadap penurunan kecemasan pada pasien kanker. Desain penelitian yang digunakan adalah literature review. Pencarian artikel yang akan di bahas menggunakan beberapa data base, antara lain Pubmed, google scholar, dengan kata kunci hipnosis, hipnosis pada pasien kanker, efektivitas hipnosis, hipnosis untuk menurunkan kecemasan. Jenis artikel yang digunakan adalah artikel penelitian. Artikel yang terkumpul diseleksi kembali berdasarkan kriteria inklusi, yakni: 1) Tujuan artikel adalah untuk menganalisis pengaruh hipnosis terhadap penurunan kecemasan pada pasien kanker, 2) Penelitian eksperimen dan kualitatif. Kriteria Eksklusi, yakni: 1) bukan artikel full text, 2) Artikel yang menggunakan bahasa selain bahasa Indonesia dan inggris. Setelah pencarian berdasarkan kata kunci didapatkan 791 artikel dari seluruh data base yang digunakan. Kemudian dilakukan seleksi artikel, terpilih 6 artikel yang memenuhi kriteria inklusi, 5 artikel menunjukkan adanya pengaruh hipnosis terhadap penurunan kecemasan pada pasien kanker, 1 artikel yang menyebutkan hipnosis dengan 3 tahap lebih optimal untuk menurunkan kecemasan yaitu; self hipnosis, sugesti, visualisasi pemberian anchoring. Berdasarkan hal tersebut di atas disimpulkan bahwa hipnosis mempunyai pengaruh terhadap penurunan kecemasan pada pasien kanker.
\end{abstract}

\section{Corresponding Author:}

Gandi Iswanto

Program Studi Magister Ilmu Keperawatan Universitas Hasanuddin Makassar

Telp. 0813426777432

Email: gandiiswanto45@gmail.com

\section{PENDAHULUAN}

Kanker adalah istilah generik untuk sekelompok besar penyakit yang dapat mempengaruhi bagian tubuh mana pun. Salah satu ciri khas kanker adalah menciptakan sel abnormal yang cepat tumbuh melampaui batas normal dan kemudian dapat menyerang bagian tubuh yang berdampingan dan menyebar ke organ lain (World Health Organization, 2017).

Pada negara-negara berkembang seperti Indonesia, kanker serviks menempati urutan kedua terbanyak setelah kanker payudara dan 
terus mengalami peningkatan setiap tahun. Berdasarkan Data Riset Kesehatan Dasar 2018, Badan Penelitian dan Pengembangan Kesehatan, Kementerian Kesehatan RI dan Data Rutin Subdit Pengendalian Penyakit Kanker Dit. Penanggulangan Penyakit Tidak Menular, Ditjen Pemberantasan Penyakit dan Penyehatan Lingkungan, Kementerian Kesehatan RI. Prevalensi kanker berdasarkan diagnosis dokter per mil yaitu sebesar 2.06 per mil kasus kanker terjadi di perkotaan dan 1,47 per mil terjadi di pedesaan (Riskesdas, 2018).

Studi yang meneliti prevalensi gangguan mental pada kanker menunjukkan bahwa sebagian besar pasien kanker tidak memenuhi kriteria diagnostik untuk gangguan mental tertentu Namun banyak pasien yang mengalami berbagai respons emosional yang sulit. Distress psikososial ada pada kontinum mulai dari masalah penyesuaian normal melalui gangguan penyesuaian. Ringkasan ini berfokus terutama pada akhir yang kurang parah dari masalah penyesuaian normal, gangguan psikososial, gangguan penyesuaian, dan kecemasan terkait kanker (NCBI, 2018).

Literature review ini bertujuan membahas pengaruh hypnoterapi terhadap penurunan kecemasan pada pasien kanker. Dalam penulisan ini akan memuat mengenai hypnoterapi, kecemasan dan pengaruh hypnoterapi terhadap kecemasan.

Pada prinsipnya, proses hipnosis dapat berlangsung disebabkan adanya gap duration dalam berlangsungnya perjalanan impuls penalaran atas suatu impuls yang diterima, dalam perjalanan respon sebagai reaksi terhadap suatu impuls, serta terjadinya atau munculnya reaksi, yang diakibatkan adanya kelambatan berlangsungnya proses tersebut.

Proses terjadinya gap duration biasanya di saat melamun, pikiran tidak fokus/tidak konsentrasi/pikiran melayang memikir hal yang tidak sesuai dengan yang sedang dihadapinya yang dilakukan pada saat yang bersamaan, atau terpana terhadap sesuatu hal, atau di saat loading otak penuh disebabkan memikirkan sesuatu hal lain untuk mencari Solusi sesuatu hal, dalam keadaan di saat manusia target atas sesuatu hal misalnya di saat mencapai atau mengejar tenggat waktu dalam pekerjaan, dalam belajar, di saat mengejar target pekerjaan atau konsentrasi dalam sesuatu hal, dalam keadaan rutinitas kerja monoton, berada dalam kejenuhan ritme keseharian, atau yang sering disebut dalam istilah gaul sekarang, bahwa otak dalam keadaan blank, telmi atau Zola.

Di saat terjadi gap duration tersebut, maka mulailah pemberian kalimat-kalimat sugesti dapat memasuki alam pikir manusia untuk memasuki alam pikir bawah sadar (memasuki fase hipnotik) (Setengah, 2016). Efektivitas hipnoterapi dalam pengobatan kecemasan pada pasien kanker yang menerima perawatan paliatif, kecemasan biasanya dikaitkan dengan reaksi terhadap diagnosis, pengobatan dan hasil yang mungkin. Meskipun dukungan untuk hipnoterapi sebagai sumber daya untuk pengentasan tekanan psikologis dan emosional, ada kekurangan bukti untuk mendukung penggunaan hipnoterapi untuk menghilangkan gejala. Studi literatur ini adalah untuk menilai manfaat dari hipnoterapi dalam pengelolaan kecemasan pada pasien perawatan paliatif dan untuk memastikan apakah hipnoterapi bisa mempengaruhi gejala lainnya termasuk depresi dan gangguan tidur (Plaskota et al., 2012).

\section{METODE PENELITIAN}

Studi Literatur ini menggunakan desain literature review. Pencarian artikel yang dibahas dalam studi literatur menggunakan beberapa data base, antara lain Pubmed, Wiley Online, Google Scholar dalam rentang waktu dari 2010 - 2020. Kata kunci yang digunakan untuk mencari artikel tersebut adalah hipnosis pada pasien kanker, penurunan kecemasan pada pasien kanker, hipnosis untuk menurunkan kecemasan pada pasien kanker.

Artikel yang muncul di halaman pencarian kemudian disaring kembali menggunakan filter jenis artikel. Artikel yang terkumpul kemudian diseleksi kembali dengan menggunakan kriteria inklusi, yakni: 1) Tujuan artikel adalah untuk menganalisis pengaruh hipnosis terhadap penurunan kecemasan pada pasien kanker, 2) Penelitian eksperimen dan kualitatif. Kriteria Eksklusi, yakni: 1) bukan artikel full text, 2) Artikel yang menggunakan bahasa selain Bahasa Indonesia dan Inggris.

\section{HASIL PENELITIAN}

Pada studi literatur ini penulis mengambil 5 sampel penelitian terkait pengaruh hipnosis terhadap penurunan kecemasan pada pasien kanker dan terdapat 1 artikel yang memperkuat 3 tahap dalam hipnosis yaitu: self hipnosis, sugesti, visualisasi Pemberian 
anchoring. Selanjutnya hasil penelitian akan dipaparkan pada tabel 1.

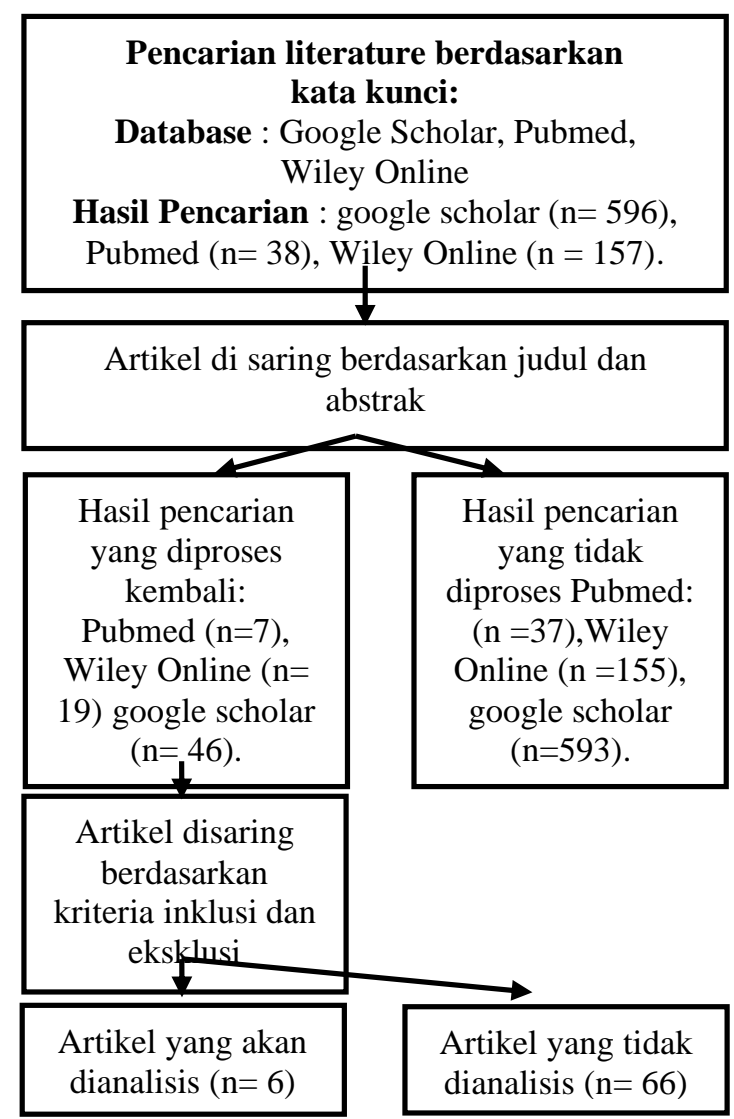

Gambar 1. Bagan Pencarian Artikel

\section{PEMBAHASAN}

Bukti hipnosis dapat membantu menurunkan tingkat kecemasan dengan beberapa penelitian dan alat ukur yang digunakan dalam setiap penelitian yang terkait hipnosis, akan tetapi sampai saat ini masih banyak perdebatan tentang sistem saraf atau pun hormon yang dipengaruhi oleh hipnosis, sehingga bisa menurunkan tingkat kecemasan pada pasien kanker (Fathi et al., 2018)

Hipnosis yang sangat mendalam dan tingkat suggestible tinggi akan memberikan efek hypnosis yang signifikan terhadap penurunan kecemasan pada pasien kanker (Guna et al., 2018). Efektivitas dari hipnosis sangat berpengaruh pada sumber stresor, dimana hipnosis bekerja untuk membuat suasana hati rileks dan membuat rasa nyaman pada tubuh yang membantu proses penurunan kecemasan, akan tetapi hipnosis dapat dipengaruhi oleh sumber stresor. Semakin tinggi tingkat stresor, maka akan mempengaruhi hipnosis pada pasien kanker. (Setengah, 2016)

Hipnosis dengan 3 tahap yaitu; self hipnosis, sugesti, visualisasi pemberian anchoring mempunyai pengaruh yang sangat optimal terhadap penurunan kecemasan. (Plaskota et al., 2012). Tingkat suggestible mempunyai pengaruh yang sangat besar terhadap keberhasilan dari terapi hipnosis. Semakin tinggi tingkat suggestible pasien, maka semakin tinggi pula tingkat keberhasilan dari hipnosis. Selain tingkat suggestible hal lain yang mempunyai pengaruh terhadap keberhasilan terapi hipnosis adalah daya fokus seseorang dalam menjalani terapi (Setengah, 2016).

Kecemasan adalah perasaan takut yang tidak menyenangkan dan biasa sering disertai dengan gejala fisiologis. Di dalam kondisi ini terapi hipnosis mempunyai peran untuk membuat suasana hati pasien menjadi rileks dan nyaman yang akan merangsang otak prefrontal untuk mensekresi hormon dopamin yang membuat suasana dan hati menjadi sangat rileks (Irianto, 2014).

Pada gangguan kecemasan terkadang mempunyai unsur penderitaan yang bermakna dan menimbulkan gangguan fungsi yang disebabkan oleh kecemasan tersebut. Dalam situasi ini hipnosis berperan untuk menstimulasi sistem limbik yang akan mensekresi hormon dopamin untuk membuat rileks dan secara perlahan akan menekan sumber stresor yang mengakibatkan rasa cemas (Plaskota et al., 2012).

\section{KESIMPULAN DAN SARAN}

Berdasarkan hasil studi literatur yang dianalisis, membuktikan bahwa masih sedikit artikel yang membahas hipnosis terkhusus ke pasien kanker yang mengalami kecemasan. Namun hipnosis mempunyai pengaruh terhadap penurunan kecemasan dibandingkan dengan pasien yang tidak menggunakan hipnosis.

Hipnosis adalah salah satu terapi keperawatan komplementer yang dapat digunakan sebagai terapi alternatif dalam menangani kecemasan yang sering di alami oleh pasien dengan kasus kanker. Melalui studi literatur ini disarankan perawat mampu mengaplikasikan hipnosis sebagai salah satu keperawatan komplementer untuk menangani kecemasan pada pasien kanker. 
Tabel 1. Deskripsi Artikel Penelitian

\begin{tabular}{|c|c|c|c|c|}
\hline Penulis & $\begin{array}{c}\text { Desain } \\
\text { Penelitian }\end{array}$ & Intervensi & Sampel & Hasil \\
\hline $\begin{array}{l}\text { Marek Plaskota et } \\
\text { al., (2012) }\end{array}$ & Eksperimen & $\begin{array}{l}\text { Memberikan hipnosis } \\
\text { dengan } 3 \text { tahap: } \\
\text { 1. self hipnosis } \\
\text { 2. sugesti } \\
\text { 3. visualisasi Pemberian } \\
\text { anchoring }\end{array}$ & $\begin{array}{c}\text { Sampel } \\
\text { sebanyak } \\
23 \\
\text { pasien }\end{array}$ & $\begin{array}{l}\text { Pengukuran dilakukan pada pra } \\
\text { dan pre hipnosis dengan } \\
\text { menggunakan skala SRAS (Self } \\
\text { Rating Anxiety Scale) didapatkan } \\
\text { nilai P: } 0,05 \text { (Plaskota et al., 2012) }\end{array}$ \\
\hline $\begin{array}{l}\text { Nunns, Michael } \\
\text { Mayhew, } \\
\text { Dominic } \\
\text { Ford, Tamsin } \\
\text { Rogers, } \\
\text { Morwenna } \\
\text { Curle, Christine } \\
\text { Logan, Stuart } \\
\text { Moore, Darren } \\
\text { (2018) }\end{array}$ & $\begin{array}{l}\text { Sistematic } \\
\text { Review }\end{array}$ & $\begin{array}{l}\text { Membandingkan delapan } \\
\text { uji hipnosis dan tujuh uji } \\
\text { non hipnosis }\end{array}$ & $\begin{array}{c}15 \\
\text { sampel }\end{array}$ & $\begin{array}{l}\text { Pengukuran kecemasan pada } \\
\text { kelompok intervensi didapatkan: } \mathrm{d} \\
=2.30 ; 95 \% \text { CI: } 1.30 \text { hingga } 3.30, \\
\text { p <0.001. Kelompok kontrol }(\mathrm{d}= \\
0,41 ; \text { CI } 95 \% \text { : }-0,56 \text { hingga } 1,38, \mathrm{p} \\
=0,41) \text {. } \\
\text { Hipnosis mempunyai pengaruh } \\
\text { yang signifikan terhadap } \\
\text { penurunan kecemasan (Nunns et } \\
\text { al., 2018). }\end{array}$ \\
\hline $\begin{array}{l}\text { Wiwit Febrina, } \\
\text { Yenni \& Stevani } \\
\text { Ramadhan (2018) }\end{array}$ & Intervensi & $\begin{array}{l}\text { Memberikan terapi hipsosis } \\
\text { pada anak penderita kanker } \\
\text { umur } 7 \text { sampai } 15 \text { tahun }\end{array}$ & $\begin{array}{c}54 \\
\text { pasien }\end{array}$ & $\begin{array}{l}\text { didapatkan hasil awal P: } 0.05 \text { dan } \\
\text { setelah diberikan hipnosis } \\
\text { menjadi p: } 0.002 \text { (Guna et al., } \\
\text { 2018). }\end{array}$ \\
\hline Sakiyan (2014) & Intervensi & $\begin{array}{l}\text { Membandingkan delapan } \\
\text { uji hipnosis dan tujuh uji } \\
\text { non hipnosis }\end{array}$ & $\begin{array}{c}15 \\
\text { sampel }\end{array}$ & $\begin{array}{l}\text { Interpretasi data menggunakan } \\
\text { Nvivo perangkat lunak 9.0.204.0, } \\
\text { penurunan kecemasan pada } \\
\text { hypnotherapi tahap } 1 \text { adalah } \\
\text { sebanyak 15,8, pada tahap } 2 \\
\text { sebanyak 7, pada tahap } \\
\text { Hypnotherapi tahap } 3 \text { sebanyak } \\
9,83 \text {. (Sakiyan, 2014). }\end{array}$ \\
\hline $\begin{array}{l}\text { Natosba et al } \\
\text { (2019) }\end{array}$ & $\begin{array}{l}\text { Deskriptif } \\
\text { kuantitatif }\end{array}$ & $\begin{array}{l}\text { Pasien diberikan Terapi } \\
\text { Progressive Muscle } \\
\text { Relaxation (PMR) dan } \\
\text { Hipnosis }\end{array}$ & $\begin{array}{c}33 \\
\text { Pasien } \\
\text { Kanker } \\
\text { Seviks }\end{array}$ & $\begin{array}{l}\text { Alat pengukuran kecemasan } \\
\text { menggunakan kuesioner Zung } \\
\text { Self-Rating Anxiety Scale } \\
\text { (SAS/SRAS)Skor } \quad \text { kecemasan } \\
\text { pasien kanker serviks sebelum dan } \\
\text { setelah diberikan intervensi PMR } \\
\text { sebesar } 16 \quad \text { sedangkan } \\
\text { hypnotherapy } 21 \text { dan } \\
\text { (Natosba et al., 2019) }\end{array}$ \\
\hline Irianto $(2014)$ & $\begin{array}{c}\text { Quasi } \\
\text { Experiment }\end{array}$ & $\begin{array}{l}\text { One group pretest dan } \\
\text { posttest design }\end{array}$ & $\begin{array}{c}47 \\
\text { Pasien } \\
\text { Kanker }\end{array}$ & $\begin{array}{l}\text { Hasil penelitian menunjukkan } \\
\text { tingkat kecemasan } \\
\text { pemberian hipnoterapi terbanyak } \\
\text { pada skala sedang sebanyak } 23 \\
\text { responden }(48,9 \%) \text {. Sedangkan } \\
\text { setelah pemberian hipnoterapi } \\
\text { didapatkan hasil tingkat } \\
\text { kecemasan menurun menjadi skala } \\
\text { normal sebanyak } 20 \text { responden } \\
(42,6 \%) \text { Uji Wilcoxon }(\mathrm{p}=0,000) \\
(\text { Irianto, 2014). }\end{array}$ \\
\hline
\end{tabular}

Tabel 2. Efektivitas Hipnosis dan Kelemahan dalam Beberapa Studi

\begin{tabular}{cll}
\hline \multicolumn{1}{c}{ Jenis } & \multicolumn{1}{c}{ Efektivitas } & \multicolumn{1}{c}{ Kelemahan } \\
\hline $\begin{array}{c}\text { Hipnosis dengan tiga tahap } \\
\text { (Plaskota et al., 2012). }\end{array}$ & Sugesti lebih optimal. & - \\
\hline $\begin{array}{l}\text { Hipnosis Lima Jari } \\
\text { (Guna et al., 2018). }\end{array}$ & $\begin{array}{l}\text { Waktu lebih cepat dan lebih } \\
\text { mudah diaplikasikan. }\end{array}$ & $\begin{array}{l}\text { Tingkat sugesti tidak dapat optimal, } \\
\text { maka perlu sugesti yang lebih } \\
\text { mendalam. }\end{array}$ \\
\hline $\begin{array}{c}\text { Dampak Hipnosis terhadap pasien } \\
\text { kanker yang akan menjalani operasi } \\
\text { (Coveney et al., 2011). }\end{array}$ & $\begin{array}{l}\text { Mempunyai pengaruh terhadap } \\
\text { penurunan kecemasan. }\end{array}$ & $\begin{array}{l}\text { Bila stresor meningkat, maka hipnosis } \\
\text { bisa mengalami penurunan dan bisa } \\
\text { memicu timbulnya kecemasan kembali. }\end{array}$ \\
\hline
\end{tabular}




\section{DAFTAR PUSTAKA}

Coveney, E., Grieve, M., \& Kumar, B. (2011). Impact of therapeutic hypnosis on pain and anxiety in patients undergoing breast cancer surgery. European Journal of Surgical Oncology, 37(11), 1002. https:// doi.org/10.1016/j.ejso.2011.08.103.

Fathi, F., Janbabai, G., Pourasghar, M., Branch, S., Cancer, G., \& Sciences, B. (2018). Efficiency of Hypnotherapy on Reducing Pain and Death Anxiety, and Increasing Resilience and Improvement of Cancer Cells in Patients with Acute Myeloid Leukemia. 28(168), 133-149.

Guna, D., Tugas, M., Tengah, U., Kuliah, M., Informasi, S., Menghadapi, A., Caesarea, S., Sakit, R., Palembang, M., Palembang, M., Kunci, K., Wiwit Febrina, Y. \& S. R., Feasibilitas, A., \& Event, M. (2018). Pengaruh Five Fingers Technique terhadap Kecemasan Pasien Kanker Payudara yang Menjalani Kemoterapi di Rumah Sakit Umum Pusat dr. Mohammad hoesin. Jurnal Ilmiah Keperawatan (Scientific Journal of Nursing), 1(2), 1-9.

Irianto, A. (2014). Pengaruh Hipnoterapi Terhadap Penurunan Tingkat Kecemasan pada Pasien Kanker Yang Menjalani Kemoterapi. 1-10. http://112.78.40.115/e-journal/index.php/ ilmukeperawatan/article/view/253/278.

Natosba, J., Rahmania, E. N., \& Lestari, S. A. (2019). Studi Deskriptif: Pengaruh Progressive Muscle Relaxation Dan Hypnotherapy Terhadap Nyeri Dan Kecemasan Pasien Kanker Serviks Descriptive Study: the Effect of Progressive Muscle Relaxation and Hypnotherapy on Pain and Anxiety of Cervical Cancer Patients.
NCBI. (2018). Adjustment to Cancer Anxiety and Distress (PDQ®)-PDQ Cancer Information Summaries-NCBI Bookshelf. https://www.ncbi.nlm.nih. gov/books/ NBK65960/.

Nunns, M., Mayhew, D., Ford, T., Rogers, M., Curle, C., Logan, S., \& Moore, D. (2018). Effectiveness of non pharmacological interventions to reduce procedural anxiety in children and adolescents undergoing treatment for cancer: A systematic review and metaanalysis. Psycho-Oncology, 27(8), 18891899. https://doi.org/10.1002/pon.4749.

Plaskota, M., Lucas, C., Pizzoferro, K., Saini, T., Evans, R., \& Cook, K. (2012). Plaskota2012. A Hypnotherapy Intervention for the Treatment of Anxiety in Patients with Cancer Receiving Palliative Care, 18(2), 69-75.

Riskesdas, K. (2018). Hasil Utama Riset Kesehata Dasar (RISKESDAS). Journal of Physics A: Mathematical and Theoretical, 44(8), 1-200. https://doi.org /10.1088/1751-8113/44/8/085201.

Sakiyan. (2014). Action Research Hypnotherapi Pada Penanganan Nyeri dan Kecemasan Pasien Kanker Kolon. https://www. ejournalwiraraja.com/index.php/JIK/artic le/view/121.

Setengah, Obee Delapan. (2016). Hipnosi Go. Bintang Wahyu.

World Health Organization. (2017). Cancer. In Cancer Fact Sheet 297. http://www.who.int/mediacentre/factshee ts/fs297/en/. 